\title{
Biological Fertilization as an Attenuation of Salinity Water on Beetroot (Beta vulgaris)
}

\author{
Ednardo Gabriel de Sousa ${ }^{1}$, Toshik Iarley da Silva ${ }^{2}$, Thiago Jardelino Dias ${ }^{1}$, Danrley Varela Ribeiro ${ }^{1}$, \\ Álvaro Carlos Gonçalves Neto ${ }^{1}$, Leonardo Vieira de Sousa ${ }^{3}$, Anderson Carlos de Melo Gonçalves ${ }^{3}$, \\ Joana Gomes de Moura ${ }^{3} \&$ José Sebastião de Melo Filho ${ }^{3}$ \\ ${ }^{1}$ Department of Agriculture, Federal University of Paraíba, Bananeiras, Paraíba, Brazil \\ ${ }^{2}$ Department of Plant Science, Federal University of Viçosa, Viçosa, Minas Gerais, Brazil \\ ${ }^{3}$ Department Plant Science and Environmental Sciences, Federal University of Paraíba, Areia, Paraíba, Brazil \\ Correspondence: Toshik Iarley da Silva, Department of Plant Science, Federal University of Viçosa, Viçosa, \\ Minas Gerais, Brazil. E-mail: toshik.silva@ufv.br
}

Received: April 13, 2018

doi:10.5539/jas.v10n7p85

\author{
Accepted: May 8, $2018 \quad$ Online Published: June 15, 2018 \\ URL: https://doi.org/10.5539/jas.v10n7p85
}

\begin{abstract}
Salinity is one of the major obstacles of modern agriculture, especially in the semi-arid regions, since these have high rates of evaporation and water sources with high salt terrors. Thus, the present study aimed to investigate the attenuating effects of bovine biofertilizer and biological fertilizer under irrigation with saline waters on the morphological behavior of beetroots (Beta vulgaris L.). The design was randomized blocks in a factorial scheme $4 \times 2+1$, referring to the electrical conductivity of the irrigation water (ECw: $0.5,1.5,3.0$ and $6.0 \mathrm{dS} \mathrm{m}^{-1}$ ) and application of bovine biofertilizer in the absence (BIO I), and presence of Microgeo ${ }^{\circledR}$ (BIO II) and a control (without fertilization and $\mathrm{ECw} 0.5 \mathrm{dS} \mathrm{m}^{-1}$ ). No effects of the factors evaluated on the gas exchange of beetroots were observed. However, the increase of $\mathrm{ECW}$ has negative effects on phytomass and growth of this crop, as the application of bio fertilizer favors some soil chemical characteristics.
\end{abstract}

Keywords: biofertilizer, phytomass, growth, gas exchange

\section{Introduction}

Semi-arid regions, characterized by high evaporation rate of the water slides, poor soil drainage, are compelled to use the irrigation, making them productive, because of which they are susceptible to salinization (Pedrotti et al., 2015). In the Brazilian semi-arid region, the water quality oscillates at certain times of the year, as well as in the geographic positioning, in relation to the arid zone.

Among beetroot (Beta vulgaris L.) is an alternative, since it presents threshold salinity values of $7.0 \mathrm{dS} \mathrm{m}^{-1}$, classified as moderately tolerant to excess salts in advanced stages of growth (Deuner et al., 2011). This behavior expresses the ability of osmotic adjustment, presented by the beetroot.

In Brazil, beetroot, is one of the most ten vegetables grown and consumed (Marcolini et al., 2010). It is a nutritional demanding crop, requiring fertilization program capable of supplying its consumption requirement in the crop. It has productivity, between 20 and 35 tons per hectare (Filgueira, 2012).

In this perspective, Silva et al. (2013), Santos et al. (2016), Paiva et al. (2017), highlighted the favorable yield of this crop, under salinity conditions, and it can be an income alternative to semi-arid rural producers. It is very important to emphasize that the increase of organic and inorganic solutes inside the plants, the interaction between salinity and fertility, had shown a significant effect on the effects of degenerative effects of saline stress promoted by irrigation water on crops (Willadino \& Camara, 2010).

Sousa et al. (2017) working with sesame (Sensamun indicum L.); Sousa et al. (2012) studying peanut (Arachis hypogaea L.), found that the bovine biofertilizer reduced the depressive effect of salinity on morphophysiological aspects of these cultures. In view this, the aim of this study was to investigate attenuating effects of bovine biofertilizer and biological fertilizer under irrigation with saline waters in the morphological behavior of beetroot. 


\section{Material and Methods}

The experiment was carried out in a protected environment of the Agricultural Sector of the Center for Social and Agrarian Human Sciences (CCHSA), Federal University of Paraíba (UFPB), Bananeiras, PB. The used soil on this study was classified as a typical Psamitic Regolitical Neosoil, from which a composite sample had collected for physical and fertility analysis (Table 1) in the CCHSA Soil Laboratory.

Table 1. Chemical and substrate texture analyzes

\begin{tabular}{|c|c|c|c|c|c|c|c|c|c|c|c|c|c|}
\hline $\mathrm{pH}$ & $\mathrm{P}$ & $\mathrm{K}^{+}$ & $\mathrm{Na}^{+}$ & $\mathrm{H}^{+}+\mathrm{Al}^{3+}$ & $\mathrm{Al}^{3+}$ & $\mathrm{Ca}^{2+}$ & $\mathrm{Mg}^{2+}$ & SB & CTC & Sand & Silt & Clay & Texture \\
\hline & \multicolumn{3}{|c|}{ - $\mathrm{mg} \mathrm{dm}^{3}$} & \multicolumn{4}{|c|}{ - $\mathrm{cmol}_{\mathrm{c}} \mathrm{dm}^{3}$} & & & \multicolumn{3}{|c|}{ - - $\mathrm{g} \mathrm{kg}^{-1}$} & \\
\hline 5.2 & 1.2 & 42.8 & 0.04 & 1.82 & 0.05 & 0.3 & 0.08 & 0.63 & 2.35 & 892 & 84 & 24 & Sandy \\
\hline
\end{tabular}

The chemical analysis of used water (Table 2) had carried out at the Soil Laboratory of the Agricultural Sciences Center at UFPB, Areia, PB. The increasing conductivity doses (1.5, 3.0, 4.5 and $\left.6.0 \mathrm{dS} \mathrm{m}^{-1}\right)$ had prepared using a portable conductivity meter, using a control water of weir $\left(0.5 \mathrm{dS} \mathrm{m}^{-1}\right)$, belonging to the experiment site.

Table 2. Analysis and classification of salinity water levels

\begin{tabular}{|c|c|c|c|c|c|c|c|c|c|c|c|c|}
\hline $\mathrm{ECw}$ & $\mathrm{pH}$ & $\mathrm{SO}_{4}{ }^{2-}$ & $\mathrm{Mg}^{2+}$ & $\mathrm{Na}^{+}$ & $\mathrm{K}^{+}$ & $\mathrm{Ca}^{2+}$ & $\mathrm{CO}_{3}{ }^{2-}$ & $\mathrm{HCO}_{3}^{-}$ & $\mathrm{Cl}^{-}$ & SAR & CSP & Clas \\
\hline$--\mathrm{dS} \mathrm{m} \mathrm{m}^{-1}--$ & & $--\mathrm{mg} \mathrm{L}^{-1}--$ & --- & -- & 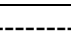 & nmolc & $\mathrm{n}^{-3}$ & & ---י & & & \\
\hline 0.5 & 7.8 & 2.65 & 0.11 & 2.24 & 0.06 & 0.10 & 0.00 & 0.9 & 2.8 & 6.92 & 8.21 & $\mathrm{C}_{2} \mathrm{~S}_{2}$ \\
\hline 1.5 & 7.1 & 19.4 & 0.17 & 8.9 & 0.06 & 0.11 & 0.00 & 1.2 & 12 & 23.79 & 25.28 & $\mathrm{C}_{3} \mathrm{~S}$ \\
\hline 3.0 & 7.3 & 3.69 & 0.17 & 15.2 & 0.07 & 0.11 & 0.00 & 0.8 & 21 & 40.69 & 37.01 & $\mathrm{C}_{3} \mathrm{~S}$ \\
\hline 6.0 & 7.2 & 5.51 & 0.16 & 32.6 & 0.08 & 0.13 & 0.00 & 1.0 & 46 & 85.70 & 55.58 & $\mathrm{C}_{4} \mathrm{~S}$ \\
\hline
\end{tabular}

Note. $\mathrm{ECW}=$ Electrical conductivity; $\mathrm{SAR}=$ Sodium Adsorption Ratio; $\mathrm{CSP}=$ Changeable Sodium Percentage; Clas $=$ Water classification

The evaluated treatments were biofertilizer without Microgeo ${ }^{\circledR}$ (BIO I), prepared in the proportion 1:1, produced by aerobic and biofertilizer process with Microgeo ${ }^{\circledR}$ (BIO II), prepared using the same process mentioned above. However, the last one had produced with $15 \%$ bovine manure, $5 \%$ Microgeo $^{\circledR}$ and completing with $80 \%$ water $\left(0.5 \mathrm{dS} \mathrm{m}^{-1}\right)$. These fertilizer had conditioned in plastic containers with $100 \mathrm{dm}^{3}$ capacity, uncovered, guaranteeing the continuous process of aerobic fermentation (Table 3).

Table 3. Chemical composition of fertilizers after maturation

\begin{tabular}{llllllllll}
\hline Biofertilizer & $\mathrm{N}$ & $\mathrm{P}$ & $\mathrm{K}^{+}$ & $\mathrm{Ca}^{+2}$ & $\mathrm{Mg}^{+2}$ & $\mathrm{~S}$ & $\mathrm{Na}^{+}$ & $\mathrm{pH}$ & $\mathrm{EC}$ \\
\hline Without Microgeo $^{\circledR}$ & 0.26 & 0.51 & 1.21 & 0.3 & 3.04 & 0.17 & 0.38 & 7.2 & 7.02 \\
With Microgeo $^{\circledR}$ & 0.25 & 0.18 & 1.33 & 0.24 & 1.31 & 9.39 & 0.28 & 7.5 & 5.76 \\
\hline
\end{tabular}

Note. $\mathrm{pH}=$ Hydrogen ionic potential (1:2.5) EC = Electrical conductivity.

Seeds used were the Earley Wonder (Isla ${ }^{\circledR}$ ) variety. Seeds had sown in $150 \mathrm{ml}$ pots and at 15 days after planting (DAP), they had transplanted to polyethylene pots with a capacity of $5 \mathrm{dm}^{-3}$. After transplanting, the seedlings received the biofertilizer treatments (with and without Microgee $^{\circledR}$ ), using $300 \mathrm{~mL}$ of biofertilizer without Microgeo $^{\circledR}$ (BIO I), at 1:10 dilution, according to recommendations of Silva et al. (2007) and the same volume of biofertilizer with Microgeo ${ }^{\circledR}$ (without dilution) (BIO II).

Saline water treatments started at $8 \mathrm{DAP}, 300 \mathrm{~mL}$ of water had administered by hand irrigation. The experimental units received weekly scarification in order to combat soil compaction. At 20 DAP the presence of ceroscopies (Cercospora beticola) had diagnosed, being controlled with the application of bordeaux broth.

The experimental design was a randomized complete block (DBC), with three replications, in a factorial scheme $4 \times 2+1$, referring to 4 electrical conductivities of irrigation water $\left(0.5,1.5,3.0\right.$ and $\left.6.0 \mathrm{dS} \mathrm{m}^{-1}\right)$ in soil treated 
with biofertilizer without Microgeo ${ }^{\circledR}$ (Bio I) and biofertilizer with Microgeo ${ }^{\circledR}$ (Bio II), and a control treatment, that is, without any of the organic inputs under irrigation with water of lower salt content $\left(5 \mathrm{dS} \mathrm{m}^{-1}\right)$.

Morphological, chlorophyll and gas exchange analyzes were performed at 15, 30, 45 days after transplanting (DAT). Chlorophyll a, b and total indexes (FCI) had determined with the aid of an electronic chlorophyll meter (Clorofilog ${ }^{\circledR}$ CFL1030, Falker), making three readings in each plot, selecting leaves from the middle third of the plant to obtain an average corresponding to the respective treatment (Silva et al., 2015). The gas exchange measurements had performed in the morning using an IRGA (ACD, LCPro-SD, Hoddesdon, UK) infrared gas analyzer with $300 \mathrm{~mL} \mathrm{~min}^{-1}$ air flow and coupled light source of $1200 \mu \mathrm{mol} \mathrm{m}^{-2} \mathrm{~s}^{-1}$. Where the net assimilation rate of $\mathrm{CO}_{2}(\mathrm{~A})$, intercellular $\mathrm{CO}_{2}$ concentration $(\mathrm{Ci})$, stomatal conductance (gs), transpiration rate $(\mathrm{E})$ and instantaneous carboxylation efficiency $(\mathrm{EiC})$ had evaluated.

At 75 DAT the length of the shoot $(\mathrm{cm})$, plant height $(\mathrm{cm})$, number of leaves, bulb diameter $(\mathrm{mm})$, root length $(\mathrm{cm})$ and fresh root, shoot and bulb mass $(\mathrm{g})$. Dry matter mass of the aerial part and root $(\mathrm{g})$ had determined after the fresh matter remained in the circulation oven for approximately 48 hours at a temperature of $65 \mathrm{C}$ until constant weight had obtained, using a precision scale $(0.001 \mathrm{~g})$ for calibration. At the end of the experiment, soil samples had collected for fertility analysis. Data had submitted to analysis of variance and regression using the statistical program SAS University Edition (Cody, 2015).

\section{Results and Discussion}

The leaf length at 45 days after transplanting (DAT) showed a significant effect for the isolated effect of the electrical conductivity of irrigation water (Figure 1), since plant height and leaf width did not show in any of the evaluation periods $(15,30$ and 45 DAT). No significant interaction had also noted between the factors. This situation differs from Silva et al. (2015) who concluded that water salinity and fertirrigation management interfere with growth, emphasizing the depreciation of the Early Wonder cultivar, in detriment to the osmotic adjustment in relation to Itapuã.

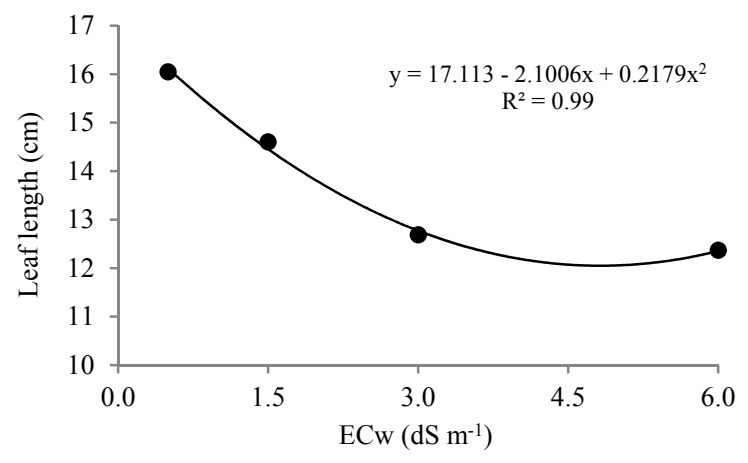

Figure 1. Leaf length (CF) of beetroot (Beta vulgaris) at 45 days (DAP) as a function of salinity of the electrical conductivity of irrigation water $(\mathrm{ECw})$

As ECw was increased, it had noted that there was a decrease on leaf length of beetroot (Figure 1). The same had observed by Santos et al. (2016), which obtained a decrease in the morphophysiological aspects of this culture under ECw of $2.85 \mathrm{dS} \mathrm{m}^{-1}$. This behavior had related to the fact that moderately salinity tolerant plants, such as beetroots, suffer from water restriction due to salinity increase, reducing the osmotic potential of soil solution, reducing water absorption capacity, resulting in morphological changes, losses of metabolic and physiological activities (Willadino \& Camara 2010).

Among all the variables evaluated at 75 DAT (shoot length, plant height, leaf number, bulb diameter, root length and fresh root, shoot and bulb mass), only the fresh shoot mass (FSM) showed interaction among the evaluated factors (Figure 2). 


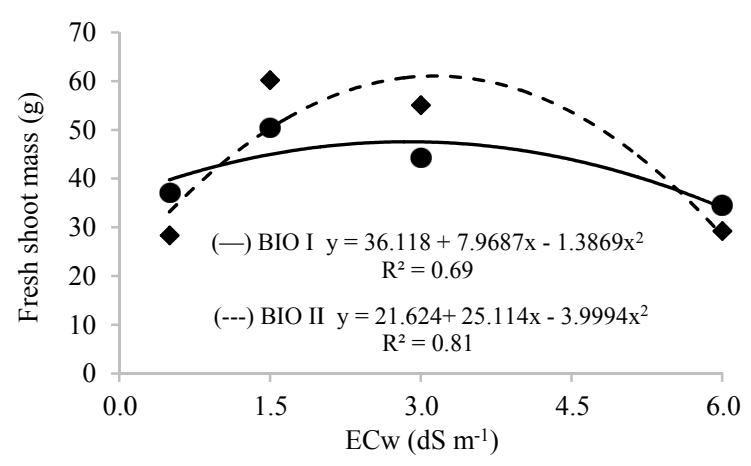

Figure 2. Interaction between biofertilizers (BIO I and BIO II) and electric conductivity of irrigation water (ECw) for fresh shoot mass of beetroot (Beta vulgaris)

The salinity increased of the irrigation water stimulated the production of FSM in the irrigated plants with water up to $3.0 \mathrm{dS} \mathrm{m}^{-1}$ reaching the highest yield $(49.63 \mathrm{~g})$. On soil, the increase of salinity caused a decline reaching $31.82 \mathrm{~g}$, resulting in losses of $64.11 \%$ among the plants irrigated with higher and lower salinity waters. Similar behavior has presented by Silva et al. (2013) in the fresh mass of the shoot of beetroot, with increased salinity of water applied via nutritive solution.

The superiority of BIO II shows a positive effect on the attenuation of deleterious effects of salinity under FSM, indicative of adjustment of the culture to the salts (Figure 2). This behavior had attributed, according to Silva et al. (2013), to the mechanisms of physiological adaptations, due to the saline stress, when reporting that plant starts to make its leaves turgid, obtaining high relative percentages of water in the foliar tissues.

Increased levels of saline water had an isolated effect on the variables bulb diameter (BD) and fresh bulb mass (FBM) (Figure 3). BD obtained linear reduction as ECw had increased. As for FBM, there was depreciation in the increase of ECw. Silva et al. (2015), observed a reduction in the bulb diameter, consequently lower mass in the cultivar Early Wonder due to water depth and saline stress.
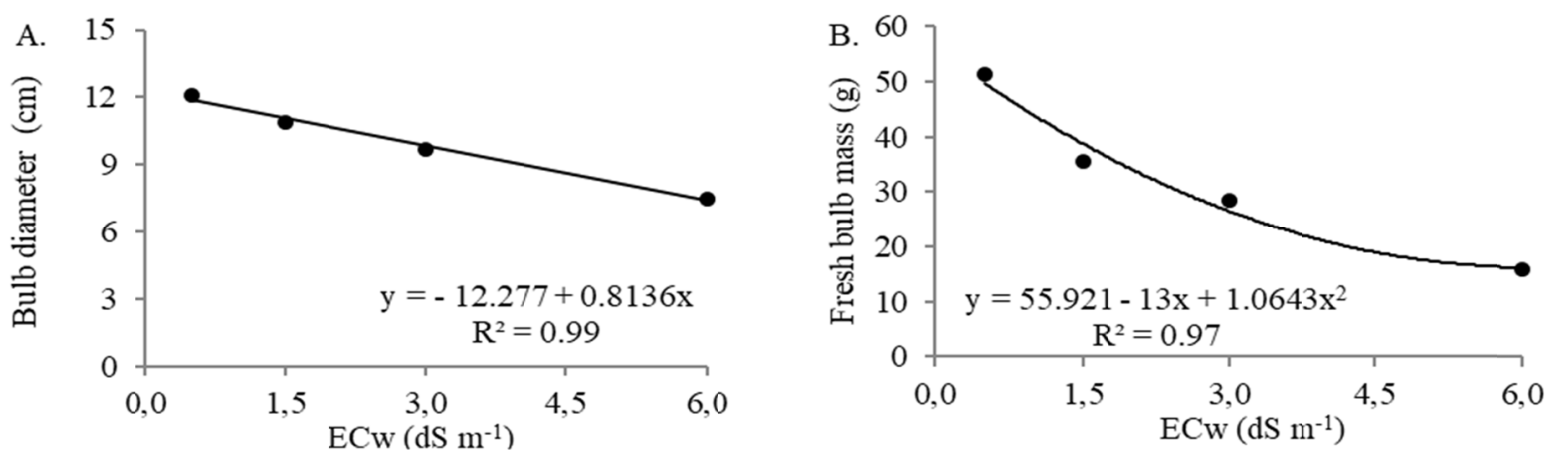

Figure 3. Bulb diameter (A) and fresh bulb mass (B) of beetroots (Beta vulgaris) in function of salinity of the electrical conductivity of irrigation water $(\mathrm{ECw})$

The results are in agreement with Alves et al. (2015) observed a reduction in the diameter of the bulb with the increase of salinity, reaching a minimum value of $3 \mathrm{~cm}$ in plants irrigated with saline water of $4.5 \mathrm{dS} \mathrm{m}^{-1}$, while in plants irrigated with water of $0.5 \mathrm{dS} \mathrm{m}^{-1}$ obtained the highest mean value of $6.57 \mathrm{~cm}$.

For gas exchanges, no significant differences had observed in any evaluated period, neither for the factors (electrical conductivity of irrigation water and biofertilizer). However, the mean values for the electrical conductivity of irrigation water (Table 4) and biofertilizers (Table 5) are showed below. 
Table 4. Mean values of stomatal conductance $(\mathrm{gs})\left(\mathrm{mol} \mathrm{H} \mathrm{H} \mathrm{m}^{-2} \mathrm{~s}^{-1}\right)$, rate of assimilation of $\mathrm{CO}_{2}(\mathrm{~A})(\mu \mathrm{mol} \mathrm{CO}$ $\left.\mathrm{m}^{-2} \mathrm{~s}^{-1}\right)$, internal carbon concentration (Ci) $\left(\mu \mathrm{mol} \mathrm{CO} \mathrm{CO}_{2} \mathrm{~m}^{-2} \mathrm{~s}^{-1}\right)$, water use efficiency (WUE) (A/E), instantaneous water use efficiency (iWUE) (A/gs), instantaneous carboxylation efficiency (EiC) (A/Ci), vapor pressure deficit (VPD) and foliar temperature (Tleaf) $\left({ }^{\circ} \mathrm{C}\right.$ ) of beetroot (Beta vulgaris) in function to the electrical conductivity of irrigation water $(\mathrm{ECw})\left(\mathrm{dS} \mathrm{m}^{-1}\right)$ at 15,30 and 45 days after transplanting (DAT)

\begin{tabular}{llllllllll}
\hline ECw & gs & A & E & Ci & WUE & iWUE & EiC & VPD & Tleaf \\
\hline $15 D A T$ & & & & & & & & & \\
0.5 & 0.191 & 15.020 & 2.212 & 202.444 & 6.797 & 78.924 & 0.080 & 5.344 & 29.067 \\
1.5 & 0.175 & 13.762 & 2.083 & 205.833 & 6.581 & 79.114 & 0.070 & 6.276 & 29.083 \\
3.0 & 0.175 & 14.888 & 2.062 & 192.833 & 7.229 & 85.915 & 0.082 & 5.974 & 28.983 \\
6.0 & 0.193 & 16.138 & 2.203 & 187.167 & 7.373 & 86.156 & 0.089 & 5.615 & 29.050 \\
\hline $30 D A T$ & & & & & & & & & \\
0.5 & 0.152 & 6.340 & 1.558 & 281.556 & 4.145 & 43.977 & 0.023 & 7.228 & 28.467 \\
1.5 & 0.170 & 6.833 & 1.707 & 288.333 & 4.011 & 42.007 & 0.025 & 6.510 & 28.433 \\
3.0 & 0.135 & 5.887 & 1.453 & 290.000 & 3.823 & 41.803 & 0.022 & 8.673 & 28.450 \\
6.0 & 0.147 & 6.710 & 1.502 & 282.167 & 4.148 & 44.519 & 0.025 & 10.700 & 28.400 \\
$45 D A T$ & & & & & & & & \\
0.5 & 0.099 & 1.828 & 1.059 & 305.222 & 2.567 & 30.063 & 0.007 & 15.478 & 29.511 \\
1.5 & 0.087 & 2.552 & 0.933 & 293.333 & 3.713 & 31.803 & 0.010 & 12.480 & 29.750 \\
3.0 & 0.067 & 1.790 & 0.923 & 319.500 & 2.245 & 29.890 & 0.006 & 29.048 & 29.733 \\
6.0 & 0.035 & 0.607 & 0.615 & 339.833 & 1.060 & 19.118 & 0.002 & 35.417 & 29.567 \\
\hline
\end{tabular}

At 15 DAT, it had observed that the stomatal conductance (gs) showed a higher average value in the ECw of 6 $\mathrm{dS} \mathrm{m}{ }^{-1}$, the same observed for the rate of assimilation of $\mathrm{CO}_{2}$ (A), water use efficiency (WUE) and instant water use efficiency (iWUE). It can be linked to acclimatization, in terms of gas exchange, to the stress to which the plant is subjected. Although at $45 \mathrm{DAT}$, it had observed that as ECw increased, there was a decrease in gs, A, E, WUE, iWUE and EiC. As a means of alleviating the stress effect, the plant can close its stomata, reducing water absorption and consequently the entrance of toxic salts. Closure of the stomata may result in a decreased transpiration, and internal $\mathrm{CO}_{2}$ concentration in leaves (Dalastra et al., 2014). Therefore, plant diminishes its photosynthetic processes, the fixation of $\mathrm{CO}_{2}$ and the production of photoassimilates.

Table 5. Mean values of stomatal conductance $(\mathrm{gs})\left(\mathrm{mol} \mathrm{H}_{2} \mathrm{O} \mathrm{m}^{-2} \mathrm{~s}^{-1}\right)$, assimilation rate of $\mathrm{CO}_{2}(\mathrm{~A})\left(\mu \mathrm{mol} \mathrm{CO}_{2}\right.$ $\left.\mathrm{m}^{-2} \mathrm{~s}^{-1}\right)$, internal carbon concentration (Ci) $\left(\mu \mathrm{mol} \mathrm{CO} \mathrm{CO}^{-2} \mathrm{~s}^{-1}\right)$, water use efficiency (WUE) (A/E), instantaneous water use efficiency (iWUE) (A/gs), instantaneous carboxylation efficiency (EiC) (A/Ci), vapor pressure deficit (DPV) and foliar temperature (Tleaf) $\left({ }^{\circ} \mathrm{C}\right)$ of beetroot (Beta vulgaris) in functioning to the application of different biofertilizers at 15,30 and 45 days after transplanting (DAT)

\begin{tabular}{|c|c|c|c|c|c|c|c|c|c|}
\hline Biofertilizantes & gs & $\mathrm{A}$ & $\mathrm{E}$ & $\mathrm{Ci}$ & WUE & iWUE & $\mathrm{EiC}$ & VPD & Tleaf \\
\hline \multicolumn{10}{|l|}{$15 D A T$} \\
\hline Control & 0.197 & 12.733 & 2.320 & 232.667 & 5.508 & 64.388 & 0.057 & 5.143 & 29.000 \\
\hline Without Microgeo ${ }^{\circledR}$ & 0.163 & 14.481 & 1.976 & 189.417 & 7.256 & 88.922 & 0.081 & 6.573 & 29.067 \\
\hline With Microgeo $^{\circledR}$ & 0.203 & 15.995 & 2.278 & 197.167 & 7.057 & 79.766 & 0.086 & 5.082 & 29.042 \\
\hline \multicolumn{10}{|l|}{$30 D A T$} \\
\hline Control & 0.147 & 6.357 & 1.507 & 282.667 & 4.292 & 45.566 & 0.023 & 7.485 & 28.433 \\
\hline Without Microgeo ${ }^{\circledR}$ & 0.158 & 6.244 & 1.597 & 287.667 & 3.764 & 39.321 & 0.023 & 7.329 & 28.440 \\
\hline With Microgeo $^{\circledR}$ & 0.147 & 6.344 & 1.550 & 286.800 & 4.007 & 43.418 & 0.023 & 8.690 & 28.467 \\
\hline \multicolumn{10}{|l|}{$45 D A T$} \\
\hline Control & 0.050 & 2.217 & 0.693 & 260.333 & 4.077 & 47.000 & 0.010 & 20.556 & 30.100 \\
\hline Without Microgeo $^{\mathbb{R}}$ & 0.091 & 1.600 & 1.058 & 327.333 & 1.658 & 23.057 & 0.005 & 24.445 & 29.317 \\
\hline With Microgeo $^{\circledR}$ & 0.065 & 1.691 & 0.799 & 312.833 & 2.757 & 28.146 & 0.006 & 20.496 & 29.817 \\
\hline
\end{tabular}


For the application of biofertilizers, it had observed that at 15 DAT plants submitted to the application of Microgeo ${ }^{\mathbb{R}}$ showed a higher mean value for stomatal conductance and instantaneous carboxylation efficiency. However, during other evaluation periods, the application of this input did not show good results. The same behavior for perspiration had found by Sousa et al. (2014) at 60 days of cultivation in sesame (Sesamum indicum), fertilized with biofertilizer.

There was a significant interaction between biofertilizers and ECw to many of the components of soil fertility (potassium, sodium, potential acidity, sulfur and cation exchange capacity), as showed on Figure 4. This statistical behavior, according to Silva et al. (2011), studying the effects of saline stress on soil and biofertilizer of cowpea (Vigna unguiculata).
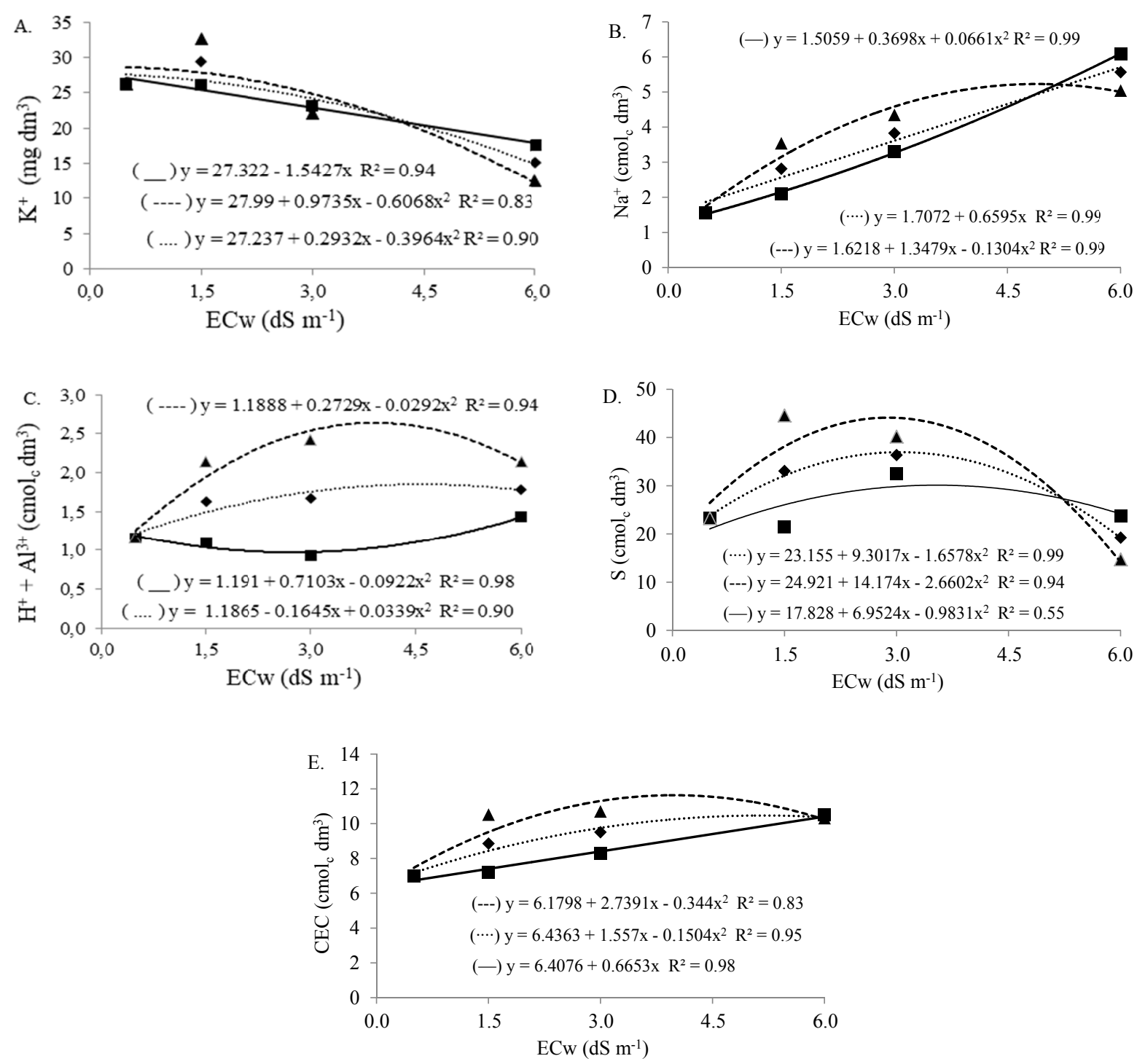

Figure 4. Effect of biofertilizers on potassium (A), sodium (B), potential acidity (C), sulfur (D) and cation exchange capacity $(\mathrm{E})$ in soil solution as a function of the electrical conductivity of water irrigation $(\mathrm{ECW}) . *(\cdots)$ Control, (-) biofertilizer I and (---) biofertilizer II

According to Sousa et al. (2012), the aforementioned interaction relates the ability of the biorfertilizer to promote adsorption of exchangeable bases by the formation of organic complexes, reducing the harmful effects of saline water. Potassium contents on soil solution had reduced as the ECW of the irrigation water had increased (Figure 4A), and reversed sodium behavior had observed (Figure 1B). According to Sá et al. (2015), the increase 
of sodium contents in soil solution favors the reduction of potassium due to the substitution of this exchangeable $\mathrm{Na}^{+}$cation. However, it had observed an increase in the potassium contents in EC to $1.5 \mathrm{dSm}^{-1}$, due to the application of the biofertilizer with Microgeo ${ }^{\circledR}$ (Figure 1A). Thus, biofertilizers provided nutritional conditions to the soil, due to the natural loss of nutrients due to leaching and consumption of the beet crop (Tivelli et al., 2011) (Figure 1A).

The increase of ECw, obtained by the addition of $\mathrm{NaCl}$, increased the $\mathrm{Na}^{+}$content in soil solution. BIO II, which did not differ statistically from BIO I and from the control, had a lower accumulation of sodium in the ECw of 6 $\mathrm{dS} \mathrm{m}^{-1}$ (Figure 4B). Miranda et al. (2011), studying chemical and organic conditioners, in the recovery of saline-sodium soil and Freire et al. (2015), obtained similar responses, when observing that the application of biofertilizer via soil, increased the sodium contents, and had elevated at the same time that the salinity of water irrigation.

Potential acidity levels in saline soil treated with BIO I had reduced when compared to soil treated with BIO II and control (Figure 4C). The soil treated with BIO II obtained high sulfur contents, reaching an optimum point in the presence of ECw $3.0 \mathrm{dS} \mathrm{m}^{-1}$, decreasing again as ECw had increased in soil solution (Figure 4D). According to Soares et al. (2017), this fact is associated to the addition of organic matter on soil, providing elevation in sulfur contents.

Treatments influenced soil CEC, obtaining a better response in the presence of BIO II, reaching an optimum point, before ECW $3.0 \mathrm{dS} \mathrm{m}^{-1}$, decreasing again after suffering elevation of DAI (Figure 4E). Costa et al. (2007), affirm that the elevation of cations contents in order to significantly influence CEC is related to organic fertilization via soil.

Organic matter, phosphorus, sum of bases and magnesium contents responded to the isolated effects of ECW (Figure 5). These results are in agreement with Sá et al. (2015), that using Microgeo ${ }^{\circledR}$ obtained an isolated effect on soil fertility in different compositions of bovine biofertilizer.
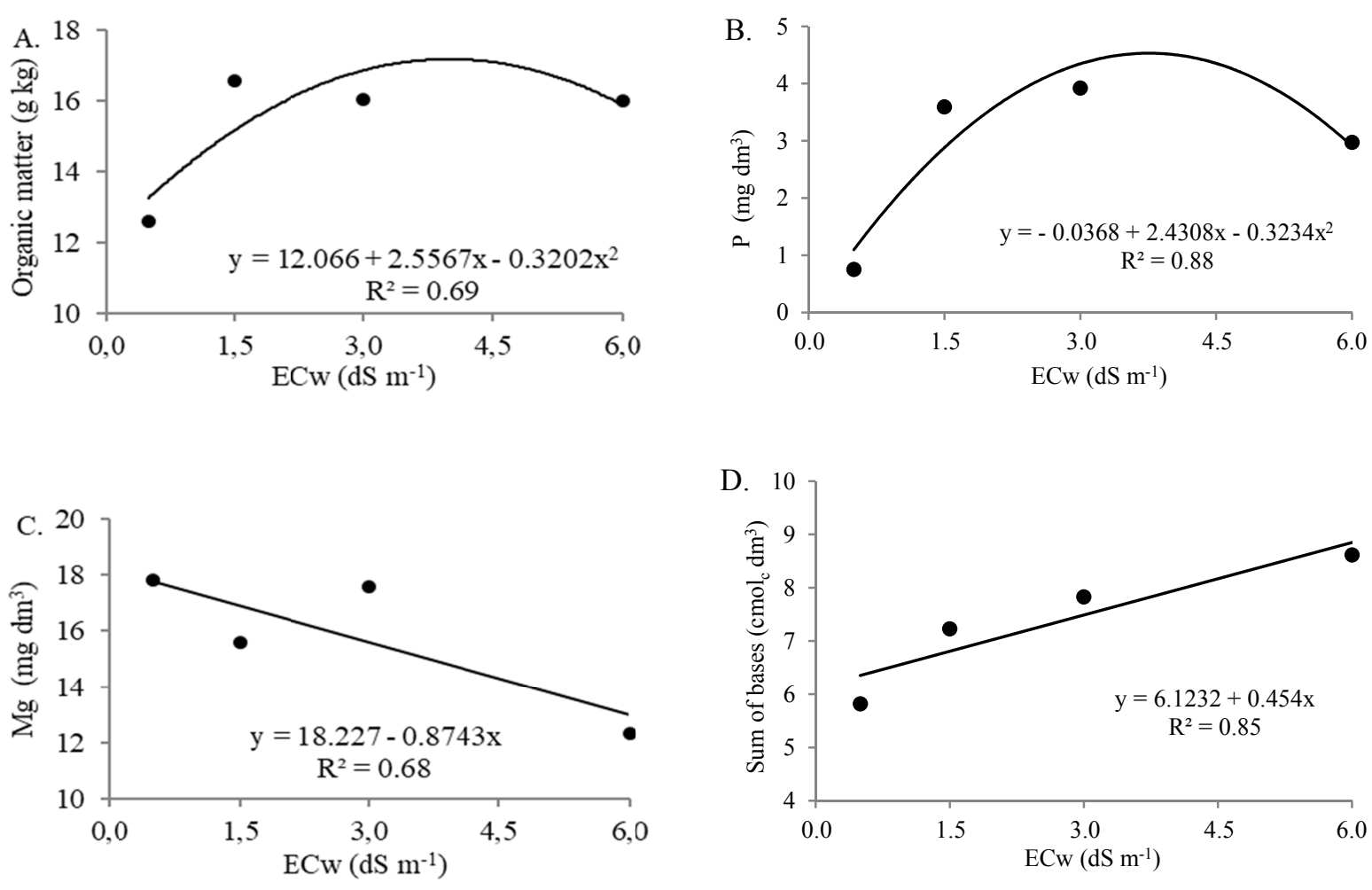

Figure 5. Organic matter content (A), phosphorus (B), magnesium (C) and sum of bases (D) in soil solution as a function of the electrical conductivity of irrigation water $(\mathrm{ECw})$ 
The organic matter content obtained an optimum point in relation to $\mathrm{ECw}$ of $1.5 \mathrm{dS} \mathrm{m}^{-1}$, decreasing again, after increasing ECw on soil solution (Figure 5A). Bellini et al. (2013) verified similar results, reporting that the biofertilizer influenced soil fertility and maintained a tendency to reduce organic matter levels. Content of phosphorus (P) was higher in ECw $3 \mathrm{dS} \mathrm{m}^{-1}$ decreasing again after elevation (Figure 5B). Ferreira et al. (2007) verified the increase in the nutrient content on soil after saline application and emphasize that it is related to the ionic strength or nutritional disorder induced by high levels of chlorine in the plant tissues, inhibiting the absorption of $\mathrm{P}$. In addition, because the reduction of $\mathrm{P}$ content on soil is due to a bigger absorption by the plant to perform its metabolic activities in the face of salt stress.

Magnesium content on soil had linearly inhibited because of increased ECW (Figure 5C). According to Garcia et al. (2007), the $\mathrm{Na}^{+} / \mathrm{Ca}^{2+}$ and $\mathrm{Na}^{+} / \mathrm{Mg}^{2+}$ ratios are directly proportional to the absorption of sodium in detriment of the calcium and magnesium absorption by the plant. However, the reduction in $\mathrm{Mg}^{2+}$ content can be attributed to water percolation due to salinity and consequently low soil permeability (Dias et al., 2010). The values of the sum of bases obtained a linear increase as a function of the increase of ECw (Figure 5D). Biofertilizers showed isolated effects for phosphorus, calcium, magnesium, base saturation and organic matter content in soil solution (Table 6).

Table 6. Levels of phosphorus, calcium, magnesium, base saturation and organic matter in the soil solution as a function of the application of biofertilizers

\begin{tabular}{|c|c|c|c|c|c|}
\hline \multirow{2}{*}{ Biofertilizers } & $\mathrm{P}$ & $\mathrm{Ca}^{2+}$ & $\mathrm{Mg}^{2+}$ & \multirow{2}{*}{$\begin{array}{l}\mathrm{V} \\
------~ \% \text {------ }\end{array}$} & \multirow{2}{*}{$\begin{array}{l}\mathrm{MO} \\
---\mathrm{g} \mathrm{kg}^{-1} \text {---- }\end{array}$} \\
\hline & --- $\mathrm{mg} \mathrm{dm}^{3}$--- & \multicolumn{2}{|c|}{-------- $\mathrm{cmol}_{\mathrm{c}} \mathrm{dm}^{3}$-------- } & & \\
\hline Control & $62.94 \mathrm{a}$ & $2.90 \mathrm{a}$ & $2.76 \mathrm{a}$ & $85.62 \mathrm{a}$ & $18.84 \mathrm{a}$ \\
\hline Without Microgeo ${ }^{\circledR}$ & $48.82 \mathrm{~b}$ & $1.71 \mathrm{~b}$ & $2.11 \mathrm{~b}$ & $87.49 \mathrm{a}$ & $14.72 \mathrm{~b}$ \\
\hline With Microgeo ${ }^{\circledR}$ & $65.18 \mathrm{a}$ & $1.91 \mathrm{~b}$ & $2.32 \mathrm{a}$ & $81.32 \mathrm{~b}$ & $22.49 \mathrm{a}$ \\
\hline
\end{tabular}

Note. Means followed by the same letter do not differ statistically by the Tukey test up to $5 \%$ probability.

The application of Microge ${ }^{\circledR}$ showed a difference related to the non-application of this input for phosphorus (P), magnesium $\left(\mathrm{Mg}^{2+}\right)$ and organic matter $(\mathrm{OM})$, but did not differ from the control. Calcium content $\left(\mathrm{Ca}^{2+}\right)$ did not show differences in the application or not of Microgeo ${ }^{\circledR}$, since for the saturation of bases (V) the application showed differences, being the absence, which obtained a better result.

\section{Conclusions}

The increase in the electrical conductivity of the irrigation water (ECw) affects leaf length, fresh shoot mass, diameter and fresh mass of beetroot bulb; ECw, neither by the application of biofertilizers, does not influence gas exchanges. Biofertilizers have attenuated the effects of $\mathrm{ECw}$ in potassium, sodium, potential acidity, sulfur and cation exchange capacity on soil solution. $\mathrm{ECw}$ has an isolated effect on levels of phosphorus, magnesium, organic matter and sum of bases; biofertilizers have an isolated effect on phosphorus, calcium, magnesium, base saturation and organic matter levels. It implies that the increase of $\mathrm{ECw}$ has a negative effect on beetroot growth and phytomass, and the application of biofertilizers favors some chemical soil characteristics.

\section{References}

Alves, L. S., Véras, M. L. M., Melo Filho, J. S., Irineu, T. H. S., \& Araújo, D. L. (2013). Irrigação com águas salinas em beterraba (Beta vulgaris L.) em função da aplicação de fertilizantes orgânicos. Revista Terceiro Incluido, 5(2), 385-397. https://doi.org/10.5216/teri.v5i2. 38795

Bellini, G., Schmidt Filho, E., \& Moreski, H. M. (2013). Influência da aplicação de um fertilizante biológico sobre alguns atributos físicos e químicos de solo de uma área cultivada com arroz (Oriza sativa). Revista em Agronegócio e Meio Ambiente, 6(2) 325-336. Retrieved from https://search.proquest.com/openview/0ceff ae6e0c43852e05c058a5061 cab3/1?pq-origsite $=$ gscholar\&cbl $=2032621$

Dalastra, G. M., Echer, M. M., Guimarães, V. F., Hachmann, T. L., \& Inagaki, A. M. (2014). Trocas gasosas e produtividade de três cultivares de meloeiro conduzidas com um e dois frutos por planta. Bragantia, 73(4), 365-371. https://doi.org/10.1590/1678-4499.206

Deuner, C., Maia, M. S., Deuner, S., Almeida, A. S., \& Meneghello, G. (2011). Viabilidade e atividade antioxidante de sementes de genótipos de feijão-miúdo submetidos ao estresse salino. Revista Brasileira de Sementes, 33(4), 711-720. https://doi.org/10.1590/S0101-31222011000400013 
Dias, N. S., \& Blanco, F. F. (2010). Efeito dos Sais no Solo e na Planta. In H. R. Gheyi, N. S. Dias, \& C. F. Lacerda (Eds.), Manejo da Salinidade na Agricultura: Estudos Básicos e Aplicados (Cap. 9, pp. 130-140). Fortaleza-CE: INCTSal.

Ferreira, P. A., Garcia, G. O., Neves, J. C. L., Miranda, G. V., \& Santos, D. B. (2007). Produção relativa do milho e teores folheares de nitrogênio, fósforo, enxofre e cloro em função da salinidade do solo. Revista Ciência Agronômica, 38, 7-12. Retrieved from http://www.redalyc.org/pdf/1953/195317477002.pdf

Filgueira, F. A. R. (2012). Novo manual de olericultura: Agrotecnologia moderna na produção e comercialização de hortaliças (p. 421). Viçosa: UFV.

Freire, J. L. O., Cavalcante, L. F., Dias, T. J., Dantas, M. M. M., Macedo, L. P. M., \& Azevedo, T. A. O. (2015). Teores de micronutrientes no solo e no tecido foliar do maracujazeiro amarelo sob uso de atenuantes do estresse salino. Agropecuária Técnica, 36, 65-81. Retrieved from http://www.okara.ufpb.br/ojs/index.php/ at/article/view/22814/12911

Garcia, G. O., Ferreira, P. A., Miranda, G. V., Neves, J. C. L., Moraes, W. B., \& Santos, D. B. (2007). Teores foliares dos macronutrientes catiônicos e suas relações com o sódio em plantas de milho sob estresse salino. Idesia (Arica), 25(3), 93-106. https://doi.org/10.4067/S0718-34292007000300010

Klimoski, R., \& Palmer, S. (1993). The ADA and the hiring process in organizations. Consulting Psychology Journal: Practice and Research, 45(2), 10-36. https://doi.org/10.1037/1061-4087.45.2.10

Marcolini, L. W., Carvalho, L. B., Cruz, M. B., Alves, P. L. C. A., \& Cecílio Filho, A. B. (2010). Interferência de caruru-de-mancha sobre características de crescimento e produção da beterraba. Planta Daninha, 28, 41-46. https://doi.org/10.1590/S0100-83582010000100005

Miranda, M. A., Oliveira, E. E. M., Santos, K. C. F., Freire, M. B. G. S., \& Almeida, B. G. (2011). Condicionadores químicos e orgânicos na recuperação de solo salino-sódico em casa de vegetação. Revista Brasileira de Engenharia Agrícola e Ambiental, 15(5), 484-490. https://doi.org/10.1590/S1415-436620110 00500008

Paiva, P. V., Valnir Júnior, M., Lima, L. S. S., Rocha, J. P. A., Demontiezo, F. L. L., \& Aragão, M. F. (2017). Avaliação de crescimento de cultivares de beterraba de mesa sob diferentes lâminas de irrigação. Revista Brasileira de Agricultura Irrigada, 11(2), 1271-1277. https://doi.org/10.7127/rbai.v11n200597

Pedrotti, A., Chagas, R. M., Ramos, V. C., Prata, A. P. M., Lucas, A. A. T., \& Santos, P. B. (2015). Causas e consequências do processo de salinização dos solos. Revista Eletrônica em Gestão, Educação e Tecnologia Ambiental, 19(2), 1308-1324.

Sá, F. V. S., Mesquita, E. F., Bertino, A. M. P., Costa, J. D., \& Araújo, J. L. (2015). Influência do gesso e biofertilizante nos atributos químicos de um solo salino-sódico e no crescimento inicial do girassol. Irriga, 20, 46-59. https://doi.org/10.15809/irriga.2015v20n1p46

Santos, D. P., Santos, C. S., Silva, P. F., Pinheiro, M. P. M. A., \& Santos, J. C. (2016). Growth and biomass beet under irrigation supplementary with water different concentrations saline. Revista Ceres, 63(4), 509-516. https://doi.org/10.1590/0034-737X201663040011

Silva, A. O. D., Klar, A. E., Silva, Ê. F. D. F., Tanaka, A. A., Junior, S., \& Josué, F. (2013). Relações Hídricas em cultivares de beterraba em diferentes níveis de salinidade do solo. Revista Brasileira de Engenharia Agrícola e Ambiental, 17(11), 1143-1151. https://doi.org/10.1590/S1415-43662013001100003

Silva, A. O., Klar, A. E., \& França, E. F. E. S. (2013). Produção da cultura da beterraba irrigada com água salina. Engenharia na Agricultura, 21(3), 271-279. https://doi.org/10.13083/1414-3984.v21n03a06

Silva, A. O., Silva, E. F. E., \& Klar, A. E. (2015). Manejo da fertirrigação e salinidade do solo no crescimento da cultura da beterraba. Revista Engenharia Agrícola, 35(2), 230-241. https://doi.org/10.1590/1809-4430-Eng. Agríc.v35n2p230-241/2015

Soares, M. M., Bardiviesso, D. M., Barbosa, W. F. S., \& Barcelos, M. N. (2017). Adubação de cobertura com enxofre na cultura da rúcula. Revista de Agricultura Neotropical, 4, 49-52. Retrieved from http://periodicosonline.uems.br/index.php/agrineo/article/view/1171/1251

Sousa, G. G., Araújo, T. V., Lacerda, C. F., Azevedo, B. M., Silva, G. L., \& Costa, F. R. B. (2014). Estresse salino em plantas de feijão-caupi em solo com fertilizantes orgânicos. Revista Agro@mbiente On-line, 8(3), 359-367. https://doi.org/10.18227/1982-8470ragro.v8i3.1824 
Sousa, G. G., Azevedo, B. M., Albuquerque, A. H. P., Mesquita, J. B. R., \& Viana, T. V. A. (2012). Características agronômicas do amendoinzeiro sob irrigação com águas salinas em solo com biofertilizantes. RevistaAgro@mbiente On-line,6(2),124-132.https://doi.org/10.18227/1982-8470ragro.v6i2.708

Sousa, G. V., Araújo, T. V., Dias, C. N., Silva, G. L., \& Azedo, B. M. (2017). Lâminas de irrigação para cultura do gergelim com biofertilizante bovino. Magistra, 26(3), 343-352. Retrieved from https://magistraonline. ufrb.edu.br/index.php/magistra/article/view/469/181

Tivelli, S. W., Factor, T. L., Teramoto, J. R. S., Fabri, E. G., Moraes, A. R. A., Trani, P. E., \& May, A. (2011). Beterraba do plantio à comercialização (p. 51). Série Tecnologia APTA. Boletim Técnico IAC 210. Campinas: IAC.

Willadino, L., \& Camara, T. R. (2010). Tolerância das plantas a salinidade: Aspectos fisiológicos e bioquímicos. Enciclopédia Biosfera, 6(11), 1-23. Retrieved from http://www.conhecer.org.br/enciclop/2010c/toleran ce\%20das\%20plantas.pdf

\section{Copyrights}

Copyright for this article is retained by the author(s), with first publication rights granted to the journal.

This is an open-access article distributed under the terms and conditions of the Creative Commons Attribution license (http://creativecommons.org/licenses/by/4.0/). 